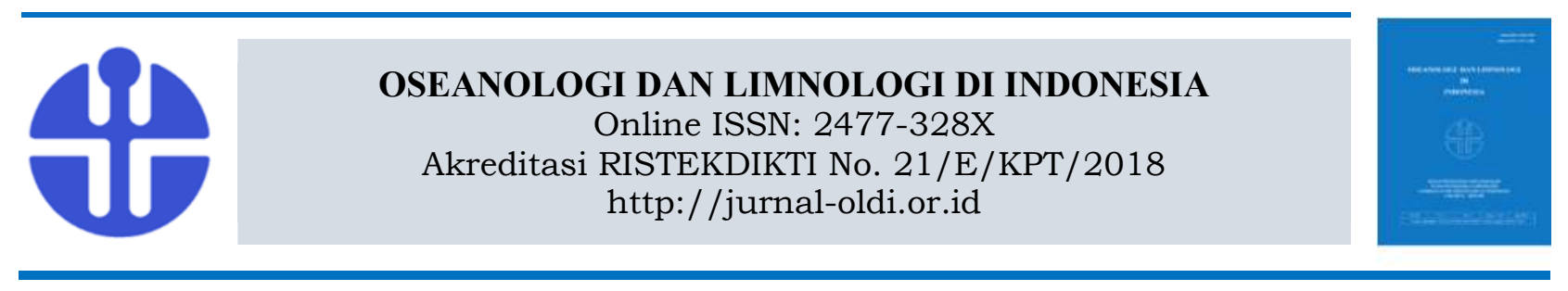

\title{
Analisis Risiko Kesehatan Pencemaran Timbal (Pb) Pada Kerang Hijau (Perna viridis) di Perairan Cilincing Pesisir DKI Jakarta
}

\author{
Anna Rejeki Simbolon \\ Pusat Penelitian Oseanografi, Lembaga Ilmu Pengetahuan Indonesia \\ Jalan Pasir Putih1, Ancol Timur, Jakarta \\ Email: anna.rejeki.simbolon@lipi.go.id; annarejekisimbolon@gmail.com
}

Submitted 15 May 2018. Reviewed 28 August 2018. Accepted 22 October 2018

DOI: 10.14203/oldi.2018.v3i3.207

\begin{abstract}
Abstrak
Perairan Cilincing merupakan salah satu muara sungai di pesisir DKI Jakarta dengan aktivitas industri dan masyarakat yang terus meningkat. Aktivitas tersebut tentunya menghasilkan limbah yang mengandung logam berat timbal dan masuk kedalam perairan. Pencemaran air akan mempengaruhi kesehatan manusia yang berinteraksi langsung maupun tidak langsung di perairan tersebut. Kerang hijau (Perna viridis) merupakan salah satu biota bentos yang dominan di Perairan Cilincing dan menjadi salah satu bahan makanan bagi masyarakat DKI Jakarta. Kerang hijau yang terpapar logam timbal pada konsentrasi tertentu akan berdampak buruk bagi kesehatan manusia. Sehingga diperlukan analisis pencemaran perairan hingga risiko kesehatan yang mungkin terjadi. Penelitian ini bertujuan untuk menganalisis risiko kesehatan pencemaran khususnya logam timbal yang terdapat pada kerang hijau terhadap manusia. Penelitian dilakukan di Perairan Cilincing, Pesisir DKI Jakarta, pada September hingga Desember 2017 dengan menggunakan metode survey untuk mengetahui kondisi lingkungan terkini. Parameter yang dianalisa antara lain, Total Suspended Solid (TSS), Logam Pb pada air, sedimen dan kerang hijau. Analisa risiko kesehatan pencemaran logam timbal dilakukan dengan menggunakan model analisis risiko SEDISOIL. Hasil penelitian menunjukkan bahwa konsentrasi logam $\mathrm{Pb}$ di sedimen dan kerang hijau jauh diatas baku mutu sehingga kerang hijau dari perairan tersebut tidak layak dikonsumsi oleh masyarakat. Hal ini terlihat dari nilai risiko kesehatan (RQ) yang telah melebihi satu pada masing-masing lokasi pengambilan sampel.
\end{abstract}

Kata kunci: pencemaran, risiko kesehatan, perairan Cilincing, pesisir DKI Jakarta

\section{Abstract}

Health Risk Assessment of Lead (Pb) Pollution in Green Mussel (Perna viridis) at Cilincing Waters, DKI Jakarta Littoral. Cilincing waters is one of the river estuaries on the coast of DKI Jakarta with increasing industrial and community activities. These activities certainly produce waste that contains heavy metal lead and into the water. Water pollution will affect the health of humans who interact directly or indirectly in these waters. Green mussel (Perna viridis) is one of the dominant benthic biota in Cilincing Waters and becomes one of the food for the people of DKI Jakarta. Green mussels exposed to lead metals at a certain concentration will adversely affect human health. So that required analysis of water pollution to health risks that may occur. This study aims to analyze the health risks of pollution, especially lead metals found in green mussel against humans. The research was conducted in Cilincing Coastal Waters of DKI Jakarta, from September to December 2017 by using survey method to determine the condition of existing environment. Parameters analyzed included Total Suspended Solid (TSS), Pb metal in water, sediment and green mussels. Health risk analysis of lead metal pollution is carried out using the SEDISOIL risk analysis 


\section{Simbolon}

model. This study shows that the concentrations of $\mathrm{Pb}$ metal in sediments and green mussels have been above the quality standard so that green mussels from that area are not feasible for consumption by the community. This is evident from the health risk (RQ) noses that have exceeded each sample location.

Keywords: contamination, health risk, Cilincing water, coastal of DKI Jakarta

\section{Pendahuluan}

Pencemaran merupakan salah satu isu yang sampai saat ini terus disoroti oleh para penggiat lingkungan. Di negara maju, isu lingkungan merupakan isu yang mendapat perhatian khusus dari pemerintah. Bukan hanya pemerintah, para akademisi, peneliti hingga lembaga swadaya masyarakat terus berperan aktif dalam mengkampanyekan kepedulian terhadap lingkungan. Sayangnya di negara berkembang, isu lingkungan belum jadi perhatian utama bagi pemerintah.Terbukti semakin maraknya kasus pencemaran yang terjadi tanpa adanya pelaksanaan regulasi yang menyeluruh dan tepat sasaran. Padahal pencemaran merupakan kejadian yang bukan hanya melibatkan ekosistem hewan dan tumbuhan dilingkungannya, namun juga manusia yang menjadi salah satu komponen dalam ekosistem.

DKI Jakarta merupakan daerah dengan tingkat perkembangan ekonomi dan industri yang meningkat setiap tahunnya. dengan tingkat kepadatan dan aktivitas industri yang tinggi. Daerah ini memiliki luas wilayah $\pm 664,01 \mathrm{~km} 2$ dengan jumlah penduduk \pm 10.075 .300 jiwa (BPS Provinsi DKI Jakarta 2015). Secara ekologis, wilayah DKI Jakarta dialiri oleh 13 sungai antara lain Sungai Mookervaart, S. Angke, S. Grogol, S. Pesanggrahan, S. Krukut, S. Sungai Baru Barat, S. Ciliwung, S. Sungai Baru Timur, S. Cipinang, S. Sunter, S. Buaran, S. Jatikramat, dan S. Cakung (PTPIN 2014). Aliran Sungai Cakung bermuara langsung ke Perairan Cilincing, Pesisir DKI Jakarta. Cilincing merupakan salah satu kawasan dengan aktivitas industri yang cukup tinggi dimana terdapat kawasan industri terpadu yang dinamakan Kawasan Berikat Nusantara. Dari sektor tingkat perekonomian, Kawasan Cilincing merupakan kawasan dengan tingkat kemiskinan penduduk tertinggi di wilayah DKI Jakarta (PTPIN 2014). Masyarakat pesisir di daerah ini umumnya bekerja sebagai nelayan kecil, penjual ikan dan pengupas kerang yang bermukim dikawasan ini antara 10 hingga 40 tahun dan menunjukkan sikap kepedulian terhadap lingkungan yang kurang baik. (Simbolon 2017)

Sebagai salah satu daerah muara sungai dan pesisir yang berbatasan dengan Laut Jawa,
Perairan Cilincing dijadikan sebagai salah satu tempat pelelangan ikan (TPI) di DKI Jakarta. Tingginya aktivitas industri dan masyarakat baik di wilayah pesisir dan di sepanjang wilayah DKI Jakarta telah memungkinkan terjadinya pencemaran di daerah tersebut. Aktivitas antropogenik akan menghasilkan limbah yang umumnya mengandung logam berat dan masuk ke perairan. Logam berat bersifat toksik dan akan terakumulasi dalam sedimen dan biota air melalui proses biokonsentrasi, bioakumulasi dan biomagnifikasi. Timbal $(\mathrm{Pb})$ merupakan salah satu indikator terjadinya pencemaran logam berat di perairan yang berasal dari aktivitas manusia. Logam $\mathrm{Pb}$ merupakan salah satu logam berat yang banyak digunakan dalam industri seperti baterai, industri percetakan (tinta), kabel, penyepuhan, pestisida, zat antiletup pada bensin, zat penyusun patri, dan sebagai formulasi penyambung pipa (Sikaily 2003).

Kerang merupakan biota air yang potensial terkontaminasi logam berat karena sifatnya yang filter feeder Timbal dapat terakumulasi dalam tubuh kerang melalui rantai makanan, yang akhirnya akan membahayakan kesehatan manusia, keadaan ini biasa disebut dengan biomagnifikasi. Sistem rantai makanan menunjukkan bahwa manusia merupakan penumpuk logam berat paling tinggi dalam tubuhnya karena berperan sebagai kosumen tingkat tinggi (Hutabarat dan Evans 2008). Salah satu biota kerang yang dominan ditemukan di wilayah Pesisir DKI Jakarta adalah kerang hijau (Perna viridis). P.viridis merupakan jenis kerang yang paling sering dijual dan dikonsumsi oleh penduduk sekitar. Selain karena harga kerang yang relatif murah, kandungan gizi yang cukup tinggi sehingga masyarakat umumnya memilih kerang sebagai bahan pangan selain ikan. Konsumsi $P$. viridis pada konsentrasi logam berat tertentu akan berpengaruh terhadap tingkat risiko kesehatan masyarakat pesisir.

Penelitian Lestari dan Edward (2004) menyebutkan kandungan logam berat di Muara Cilincing masih di bawah baku mutu dan masih dapat digunakan untuk budidaya biota air, namun Makmur et al. (2012) menyebutkan Muara Cilincing mengindikasikan terjadinya blooming dengan kandungan bahan organik yang diatas baku mutu. Simbolon (2016) menyebutkan bahwa Perairan Cilincing tergolong tercemar sedang 
dengan kandungan Chemical Oxygen Demand (COD) yang tinggi. Dari data tersebut terlihat kecenderungan penurunan kualitas air di Perairan Cilincing, namun penelitian tersebut belum mengukur kandungan logam Timbal $(\mathrm{Pb})$ baik pada air, sedimen dan kerang hijau (Perna viridis) serta kemungkinan risiko kesehatan yang ditimbulkan. Keberadaan Timbal di perairan akan mengkontaminasi ekosistem perairan, hingga terakumulasi pada biota air dan sedimen. Biota air yang mengandung Timbal pada konsentrasi tertentu dapat membahayakan biota tersebut dan bersifat toksik jika masuk ke tubuh manusia (Besser et al. 2007). Penelitian ini bertujuan untuk mengestimasi risiko kesehatan pencemaran logam Timbal terhadap masyarakat di Perairan Cilincing, Pesisir DKI Jakarta dan merumuskan manajemen risiko yang dapat dilakukan.

\section{Metodologi}

\section{Waktu dan lokasi pengambilan sampel}

Penelitian ini dilakukan di Perairan Cilincing, Pesisir DKI Jakarta pada SeptemberDesember 2017. Metode pengambilan sampel ditentukan dengan purposive sampling.
Pengambilan sampel pada tiga lokasi pengambilan sampel dan diulang sebanyak tiga kali dengan interval waktu pengambilan sampel selama dua minggu. Jarak pengambilan sampel \pm 500 meter dari pantai dengan kedalam air \pm 7.5 meter. Lokasi pengambilan sampel disajikan pada Gambar 1 dan kordinat pengambilan sampel disajikan pada Tabel 1. Parameter kualitas air yang diuji ialah Total Suspended Solid (TSS), konsentrasi $\mathrm{Pb}$ pada air, sedimen dan kerang hijau. Analisis laboratorium dilakukan di Laboratorium Produktivitas Lingkungan, Institut Pertanian Bogor.

\section{Pengambilan dan Preparasi Sampel}

Pengambilan sampel air dilakukan pada setengah kedalaman perairan dengan estimasi sampel air dari dasar dan permukaan air telah homogen. Sampel air untuk pengukuran logam diawetkan dalam larutan $\mathrm{H}_{2} \mathrm{SO}_{4}$. Sampel kerang diambil sebanyak 10-15 buah dengan ukuran yang relatif seragam. Kerang diawetkan dengan pendingin hingga suhu $4^{\circ} \mathrm{C}$ untuk dianalisa kandungan logam beratnya di laboratorium. Sampel sedimen dimasukkan ke dalam botol gelas dan diawetkan dalam pendingin hingga suhu $4^{\circ} \mathrm{C}$.

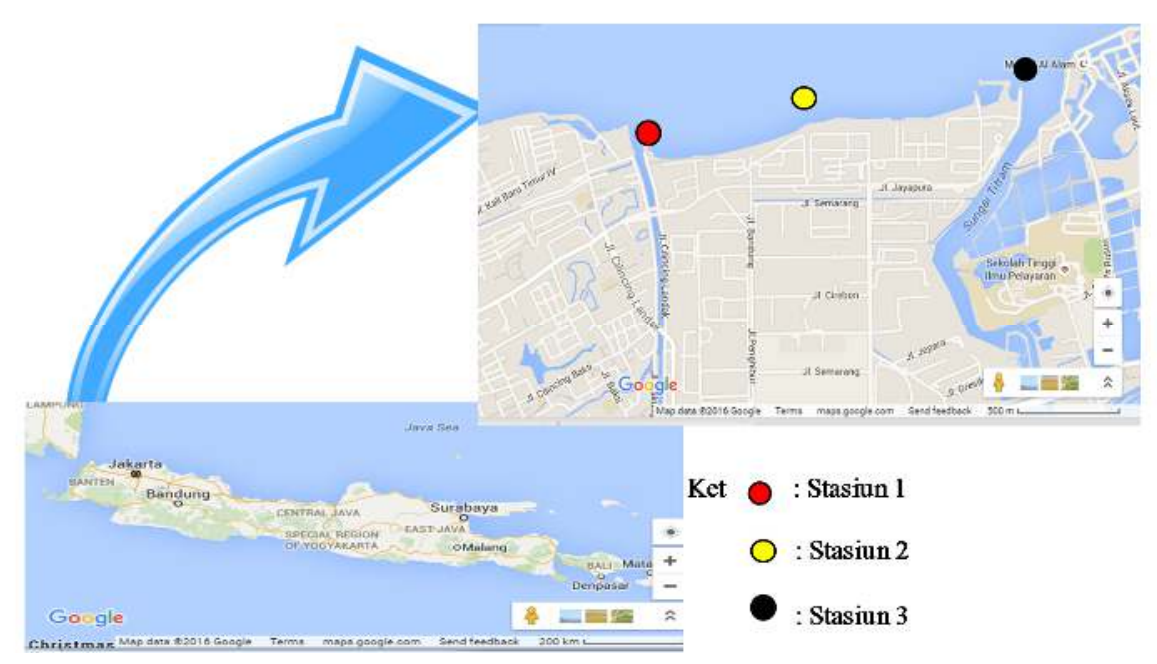

Gambar 1. Peta lokasi penelitian

Figure 1. Map of research location

Tabel 1. Titik kordinat pengambilan sampel

Table 1.Sampling coordinates

\begin{tabular}{ccc}
\hline Locations & Region Name & Coordinates \\
\hline Station 1 & Estuary of Cilincing & $6^{\circ} 5.647^{\prime} \mathrm{S} ; 106^{\circ} 56.165^{\prime} \mathrm{E}$ \\
Station 2 & Settlement Area & $6^{\circ} 4.719^{\prime} \mathrm{S} ; 106^{\circ} 56.385^{\prime} \mathrm{E}$ \\
Station 3 & Industrial zone"Kawasan Berikat Nusantara" & $6^{\circ} 4.646^{\prime} \mathrm{S} ; 106^{\circ} 57.084^{\prime} \mathrm{E}$ \\
\hline
\end{tabular}




\section{Analisa Data}

\section{Identifikasi Bahaya}

Sumber bahaya yang diidentifikasi adalah konsentrasi logam $\mathrm{Pb}$. Identifikasi logam $\mathrm{Pb}$ dilakukan dengan mengukur konsentrasinya baik di air, sedimen dan kerang hijau yang terdapat di perairan lokasi studi.

\section{Analisis Dosis-Respon}

Analisis Dosis-Respon dilakukan untuk mengetahui dosis yang terpapar pada tubuh manusia dan tidak menimbulkan efek kesehatan. Dosis ini disebut sebagai dosis referensi. Dosis referensi untuk efek-efek non-karsinogenik dinyatakan sebagai Reference Dose (RfD) sedangkan efek-efek karsinogenik dinyatakan sebagai Cancer Slope Factor (CSF). Nilai RfD dan CSF berbeda setiap logam berat dan diperoleh berdasarkan referensi yaitu: nilai RfD sebesar 0,004 (US EPA 2005) dan CSF 0,042 (Huboyo dan Syafrudin 2007).

\section{Analisis Paparan}

Tahap selanjutnya dalam analisis risiko kesehatan adalah analisis paparan. Tahap ini meliputi prakiraan alur paparan kontaminan pada media pencemar dan potensi risiko mencemari populasi. Analisis paparan pada masyarakat yang mengkonsumsi kerang hijau dilakukan dengan menghitung laju asupan kerang hijau dan frekuensi paparan per harinya. Laju asupan kerang hijau pada masyarakat Perairan Cilincing Pesisir DKI Jakarta didapatkan dengan menghitung berapa banyak kerang hijau yang dimakan oleh masyarakat per harinya. Frekuensi paparan diperoleh dengan mengetahui jumlah hari dalam satu tahun bagi masyarakat yang mengkonsumsi kerang hijau.

\section{Karakterisasi Risiko}

Karakteristik risiko adalah perkiraan suatu risiko yang merugikan yang dapat terjadi pada manusia yang diakibatkan dari paparan logam berat. Perkiraan tersebut dapat dilakukan melalui estimasi risiko, yaitu kuantifikasi probabilitas terjadinya risiko berdasarkan identifikasi bahaya, analisis efek dan analisis paparan.Tingkat risiko atau disebut RQ (Risk Quotients) adalah rasio intake dengan dosis referensi. Nilai RQ menunjukkan tingkat risiko untuk efek-efek nonkarsinogenik. Risiko kesehatan dinyatakan ada dan perlu dikendalikan jika RQ $>1$. Karakteristik risiko kesehatan untuk efek karsinogenik dinyatakan dengan ECR (Excess Cancer Risk), risiko kesehatan dinyatakan tidak diterima apabila $10^{-6}<$ ECR $-<10^{-4}$. Kisaran angka $10^{-6}$ sampai dengan $10^{-4}$ diambil dari nilai default karsinogenik (US-EPA 2005).
Persamaan yang digunakan untuk menghitung RQ adalah:

$$
\begin{aligned}
& \mathrm{RQ}=\frac{\mathrm{Ink}}{\mathrm{RfD}} \ldots \ldots \ldots \ldots \ldots(1) \\
& \text { Keterangan: } \\
& \begin{array}{ll}
\mathrm{Ink}= & \text { asupan (intake) non-karsinogenik }(\mathrm{mg} / \mathrm{kg} \\
\mathrm{bb} / \text { hari) } & \text { dosis acuan (reference dose) (mg/kg } \\
\mathrm{bfD} / \text { hari) }
\end{array}
\end{aligned}
$$

Keterangan :

$$
\begin{aligned}
\mathrm{I}= & \text { asupan }(\mathrm{mg} / \mathrm{kg} / \mathrm{hari}) \\
\mathrm{C}= & \text { konsentrasi risk agent }(\mathrm{mg} / \mathrm{l}) \\
\mathrm{R}= & \text { laju asupan atau konsumsi }(\mathrm{g} / \mathrm{hari}) \\
\mathrm{fE}= & \text { frekuensi pemaparan (hari/tahun) } \\
\mathrm{Dt}= & \text { durasi pemaparan (30 tahun untuk nilai } \\
\mathrm{Wb}= & \text { default residensial) } \\
\mathrm{t}_{\mathrm{avg}}= & \text { perat badan }(\mathrm{kg}) \\
& \text { heriode waktu rata-rata }(70 \text { tahun } \times 365 \\
& \text { atau } 30 \text { tahun } \mathrm{x} 365 \text { hari/tahun untuk zat } \\
& \text { non-karsinogen (Ink) }
\end{aligned}
$$

Paparan yang berkaitan dengan kontaminasi $\mathrm{Pb}$ dikuantifikasi dengan analisis risiko kesehatan terhadap penduduk yang melakukan aktivitas langsung di perairan tersebut (berenang, mencari ikan). Model yang digunakan adalah model analisis risiko kesehatan SEDISOIL yang dikembangkan oleh National Institute of Public Health and Environmental Protection (Albering et al. 1999) yang mencakup lima jalur pemaparan, yaitu (1) sedimen, (2) air permukaan, (3) material tersuspensi, (4) kontak kulit dengan air permukaan dan (5) kontak kulit dengan sedimen. Persamaan yang digunakan dalam model untuk menghitung total pemaparan adalah:

1) Asupan (intake) bersumber dari sedimen (mg/kg bb/hari)

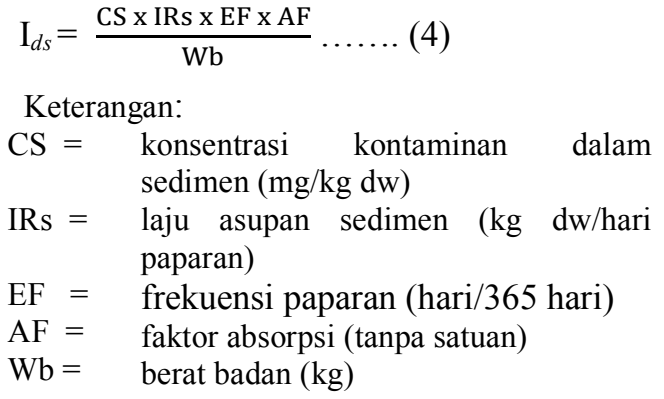

2) Asupan yang bersumber dari air permukaan (mg/kg bb/hari)

$$
\mathrm{I}_{w s}=\frac{\mathrm{CW} \times \mathrm{IRw} \times \mathrm{EF} \times \mathrm{AF}}{\mathrm{Wb}} \ldots \ldots \ldots
$$

Keterangan: 


$$
\begin{aligned}
\mathrm{CW}= & \begin{array}{l}
\text { konsentrasi kontaminan dalam air } \\
\text { permukaan }(\mathrm{mg} / \mathrm{l})
\end{array} \\
\mathrm{IRw}= & \begin{array}{l}
\text { laju asupan air permukaan (liter/hari } \\
\text { paparan) }
\end{array}
\end{aligned}
$$

3) Asupan yang bersumber dari material tersuspensi (mg/kg bb/hari):

$$
\mathrm{I}_{\mathrm{SM}}=\frac{\mathrm{CM} \times \mathrm{CMW} \times \mathrm{IRw} \times \mathrm{EF} \times \mathrm{AF}}{\mathrm{Wb}}
$$

Keterangan:

$$
\begin{array}{ll}
\mathrm{CM}= & \begin{array}{l}
\text { konsentrasi kontaminan dalam } \\
\text { material tersuspensi }(\mathrm{mg} / \mathrm{kg} \mathrm{dw}) \\
\mathrm{CMW}=
\end{array} \\
\begin{array}{l}
\text { kandungan material tersuspensi di } \\
\text { air permukaan }(\mathrm{kg} / \mathrm{liter})
\end{array}
\end{array}
$$

4) Asupan lewat kontak dermal dengan sedimen (mg/kg bb/hari) :

$$
\mathrm{Ikds}=\frac{\mathrm{Cs} \times \mathrm{SAs} \times \mathrm{AD} \times \mathrm{ASs} \times \mathrm{Mf} \times \mathrm{EDs} \times \mathrm{EF} \times \mathrm{AF}}{\mathrm{Wb}} \ldots
$$

Keterangan:

$\mathrm{SAs}=$ luas permukaan kulit untuk paparan sedimen $\left(\mathrm{m}^{2}\right)$

$\mathrm{AD}=$ laju kontak kulit dengan sedimen $\left(\mathrm{mg} / \mathrm{cm}^{2}\right)$

$\mathrm{ASs}=\quad$ laju absorpsi dermal (liter/jam)

$\mathrm{Mf}=$ faktor matriks (tanpa satuan)

EDs $=$ durasi pemaparan terhadap sedimen (jam/hari)

5) Asupan lewat kontak dermal dengan air permukaan ( $\mathrm{mg} / \mathrm{kg} \mathrm{bb} /$ hari)

$$
\mathrm{I}_{\mathrm{Kdw}}=\frac{\mathrm{Cw} \times \mathrm{SAw} \times \mathrm{ASw} \times \mathrm{EF} \times \mathrm{EDw} \times \mathrm{AF}}{\mathrm{Wb}} \ldots
$$

Keterangan:

$\mathrm{SAw}=$ luas permukaan kulit untuk pemaparan pada air permukaan $\left(\mathrm{m}^{2}\right)$

$\mathrm{ASw}=$ laju absorpsi dermal $\left[\left(\mathrm{mg} / \mathrm{m}^{2}\right) /(\mathrm{mg} /\right.$ 1)/jam]
$\mathrm{EDw}=$ durasi pemaparan (jam/hari)

Nilai default faktor-faktor pemaparan yang digunakan dalam pemodelan pemaparan untuk menghitung asupan berbagai jalur pemaparan mengacu pada nilai yang diberikan oleh Albering et al. (1999) pada Tabel 2. Nilai ini merupakan nilai referensi dari berbagai laju paparan dan parameter lain yang digunakan dalam model SEDISOIL. Nilai referensi ini terbagi dalam 2 kelompok individu yaitu dewasa dan anak-anak. Hasil penentuan total tingkat pemaparan atau asupan logam berat melalui kelima jalur pemaparan, selanjutnya dibandingkan dengan asupan harian yang dapat ditoleransi (RfD). Tingkat bahaya (RQ) ditentukan dengan membandingkan jumlah paparan harian rata-rata dengan Rfd. Nilai jumlah paparan harian rata-rata digunakan untuk mengetahui jumlah RQ dalam seluruhan populasi. Jumlah paparan harian ratarata (mg/kg bb/hari) ditentukan menggunakan persamaan (Albering et al. 1999):

$$
\begin{aligned}
& \text { Jumlah paparan harian rata-rata } \\
& =\frac{6 \mathrm{x} \text { paparan harian anak }}{70}+\frac{64 \mathrm{x} \text { paparan harian dewasa }}{7} \\
& \mathrm{RQ}=\frac{\sum \text { paparan harian rata-rata }}{\mathrm{RfD}}
\end{aligned}
$$

\section{Manajemen Risiko}

Manajemen risiko akan dilakukan apabila tingkat risiko $(\mathrm{RQ})>1$. Caranya adalah dengan mengurangi laju asupan dan frekuensi pajanan secara matematik sehingga menjadi :

$$
\begin{aligned}
R & =\frac{R f D \times W b \times t a v g}{C \times f E \times D t} \\
F e & =\frac{R f D \times W b \times t a v g}{C \times R \times D t}
\end{aligned}
$$

Tabel 2. Nilai default yang digunakan dalam model pemaparan

Table 2.The default value used in the exposure model

\begin{tabular}{lll}
\multicolumn{1}{c}{ Parameter } & \multicolumn{1}{c}{ Children } & \multicolumn{1}{c}{ Adult } \\
\hline Ingestion rate of sediment (IRs) (kg dw/exposure day) & $1 \mathrm{E}-3$ & $3.5 \mathrm{E}-4$ \\
Ingestion rate of surface water (IRw) (liter/exposure day) & $5 \mathrm{E}-2$ & $5 \mathrm{E}-2$ \\
Absorption factor (AF) & 1 & 1 \\
Dermal absorption rate (ASs) (liter/hr) & 0.01 & 0.005 \\
Dermal surface area for sediment exposure (SAs) $\left(\mathrm{m}^{2}\right)$ & 0.17 & 0.28 \\
Dermal surface area for exposure in surface water $(\mathrm{SAw})\left(\mathrm{m}^{2}\right)$ & 0.95 & 1.80 \\
Dermal adherence rate for sediment (AD) $\left(\mathrm{mg} / \mathrm{cm}^{2}\right)$ & 0.51 & 3.75 \\
Matrix factor (Mf) & 0.15 & 0.15 \\
Exposure frequency (EF) (days/365 days) & 30 & 30 \\
Body weight (BW) (kg) & 15 & 70 \\
Exposure duration to sediment (EDs) (hr/day) & 8 & 8 \\
Exposure duration in surface water (EDw) (hr/day) & 2 & 1 \\
Fraction contaminated (Fl) & 0.5 & 0.5 \\
\hline Sin
\end{tabular}

Sumber : Albering et al. (1999) 


\section{Hasil}

Jumlah kerang yang diperoleh selama penelitian dalam setiap stasiun berkisar antara 3050 buah dengan ukuran panjang antara 4-7 cm dan diameter panjang 2-3 cm. Kerang hijau yang diperoleh dalam keadaan hidup dan diambil seluruh bagian tubuhnya untuk dianalisa konsentrasi logam $\mathrm{Pb}$. Contoh kerang hijau yang diperoleh selama penelitian ditampilkan pada Gambar 2.

Konsentrasi TSS, Timbal di air, sedimen dan
kerang hijau (Perna viridis)
Pengukuran konsentrasi TSS dan konsentrasi $\mathrm{Pb}$ baik di air, sedimen dan kerang hijau disajikan pada Tabel 3. Nilai TSS yang diperoleh selama penelitian yaitu $<8 \mathrm{mg} / \mathrm{l}$ pada masing-masing stasiun pengamatan. Berdasarkan Tabel 3 konsentrasi $\mathrm{Pb}$ air yang diperoleh selama penelitian berkisar antara $0,006 \mathrm{mg} / 1-0,007 \mathrm{mg} / \mathrm{l}$ dengan kisaran yang hampir sama pada masingmasing lokasi. Sementara itu rata-rata konsentrasi $\mathrm{Pb}$ di sedimen berkisar antara 138,96 mg/kg$150,54 \mathrm{mg} / \mathrm{kg}$. Konsentrasi $\mathrm{Pb}$ sedimen paling tinggi terdapat di Stasiun 2, sementara itu konsentrasi $\mathrm{Pb}$ sedimen terendah terdapat di stasiun 1 (Gambar 3).

Kerang hijau yang diperoleh saat penelitian disajikan pada Gambar 2. Rata-rata konsentrasi $\mathrm{Pb}$ di kerang berkisar antara $6,41 \mathrm{mg} / \mathrm{kg}-9,10 \mathrm{mg} / \mathrm{kg}$ dengan konsentrasi $\mathrm{Pb}$ tertinggi terdapat di stasiun 1 dan terendah pada stasiun 2. Konsentrasi logam $\mathrm{Pb}$ di stasiun 1 berkisar antara 7,69 mg/kg - 9,85 $\mathrm{mg} / \mathrm{kg}$ dengan rata-rata $9,103 \mathrm{mg} / \mathrm{kg}$. Logam $\mathrm{Pb}$ pada kerang hijau yang diperoleh dilokasi stasiun 2 berkisar antara $6,07 \mathrm{mg} / \mathrm{kg}-6,86 \mathrm{mg} / \mathrm{kg}$ dengan rata-rata $6,41 \mathrm{mg} / \mathrm{kg}$. Sementara itu, logam $\mathrm{Pb}$ pada kerang hijau di stasiun 3 berkisar antara $5,71 \mathrm{mg} / \mathrm{kg}-8,52 \mathrm{mg} / \mathrm{kg}$ dengan rata-rata $6,77 \mathrm{mg} / \mathrm{kg}$. Penelitian ini menunjukkan konsentrasi $\mathrm{Pb}$ di kerang hijau tertinggi terdapat di Stasiun 1 yang merupakan Muara Cilincing dan terendah pada Stasiun 3 yang berlokasi di Kawasan Berikat Nusantara (Gambar 4).

\section{Risiko Kesehatan Pencemaran Logam Berat Pb di Perairan Cilincing Pesisir DKI Jakarta}

Berdasarkan wawancara terhadap masyarakat setempat, umumnya masyarakat memakan kerang hijau antara 10-20 ekor dengan rata-rata 15 ekor tiap kali makan sebanyak 3 kali dalam sehari. Berat satu ekor kerang hijau yang ditangkap berkisar antara 3-8 gram dengan ratarata 4 gram, sehingga berat kerang hijau dalam satu kali makan yaitu $15 \times 4$ gram $=60$ gram dan laju asupan kerang hijau per harinya adalah $3 \times$ 60 gram $=180$ gram $/$ hari.

202
Berdasarkan hasil wawancara, masyarakat umumnya mengkonsumsi kerang hijau hanya saat tertentu, yaitu pada musim penangkapan kerang hijau yang terjadi pada bulan Maret, Juni, September dan Desember yang berkisar 16 minggu/tahun. Saat musim penangkapan kerang hijau, masyarakat mengkonsumsi kerang hijau 3 kali dalam seminggu. Maka frekuensi paparan $(\mathrm{Fe})=3 \times 16 \mathrm{minggu}=48$ hari/tahun. Masyarakat di Perairan Cilincing Pesisir DKI Jakarta umumnya telah tinggal disana dan mengkonsumsi kerang hijau antara 20 - 40 tahun, dengan rata-rata 27 tahun (Simbolon, 2017). Sehingga durasi paparan yang digunakan ialah 27 tahun. Tingkat risiko yang diakibatkan karena konsumsi langsung kerang hijau diperoleh berdasarkan hasil perhitungan dan disajikan pada Tabel 4. Sementara itu tingkat risiko akibat aktivitas langsung disajikan pada Tabel 5 .

Tingkat risiko akibat aktivitas langsung dilakukan dengan mengetahui hasil perhitungan nilai laju asupan, frekuensi paparan serta konsentrasi logam $\mathrm{Pb}$ pada kerang dan dimasukan dalam model simulasi. Perhitungan tingkat risiko pada setiap stasiun diperoleh dengan memasukan nilai default pada model SEDISOIL. Tingkat risiko dipisahkan berdasarkan populasi masyarakat yang tergolong dewasa dan anak. Prakiraan tingkat risiko dengan estimasi waktu selama 5 tahun pemaparan. Nilai RQ akibat pencemaran logam Timbal pada setiap stasiun ditampilkan pada Tabel 4. Berdasarkan tabel tersebut, nilai RQ untuk $\mathrm{Pb}$ di Stasiun 1, Stasiun 2 dan Stasiun 3 masing-masing sebesar 1346,3, 1458,4 dan 1410,1 dimana nilai RQ tertinggi terdapat pada stasiun 2 .

Hasil simulasi analisis risiko akibat konsumsi kerang hijau di sajikan pada Tabel 5. Simulasi ini menghasilkan nilai RQ diatas satu pada setiap stasiun dan kelompok populasi. Nilai RQ pada populasi anak-anak dan dewasa di Stasiun 1 masing-masing sebesar 12929 dan 2770,55, di Stasiun 2 sebesar 9103,6 dan 1950, 85 dan di Stasiun 3 sebesar 9638,93 dan 2065,48. Hal ini menunjukkan bahwa nilai RQ lebih dari satu maka logam $\mathrm{Pb}$ yang terkandung dalam tubuh kerang hijau memiliki risiko kesehatan bagi masyarakat. Nilai ECR menunjukkan bahwa ada kasus tambahan kanker setiap 10.000 penduduk karena nilai ECR $>1 \times 10^{-4}$. Nilai ECR untuk setiap stasiun telah melebihi $10^{-4}$ hal ini menunjukkan setiap stasiun pengambilan telah berisiko terhadap efek karsinogenik akibat konsumsi kerang hijau.

\section{Manajemen Risiko Kesehatan}

Manajemen risiko pencemaran logam $\mathrm{Pb}$ di kerang hijau dapat dilakukan dengan mengubah 
laju konsumsi (R) dan frekuensi paparan (Fe) dan variabel lain dibiarkan tetap. Hasil perhitungan laju konsumsi dan frekuensi paparan ditampilkan pada Tabel 6. Berdasarkan hasil manajemen risiko pada Tabel 4 maka laju konsumsi aman kerang hijau bagi masyarakat di Perairan Cilincing Pesisir DKI Jakarta agar tidak terkena risiko kesehatan akibat paparan logam $\mathrm{Pb}$ yaitu
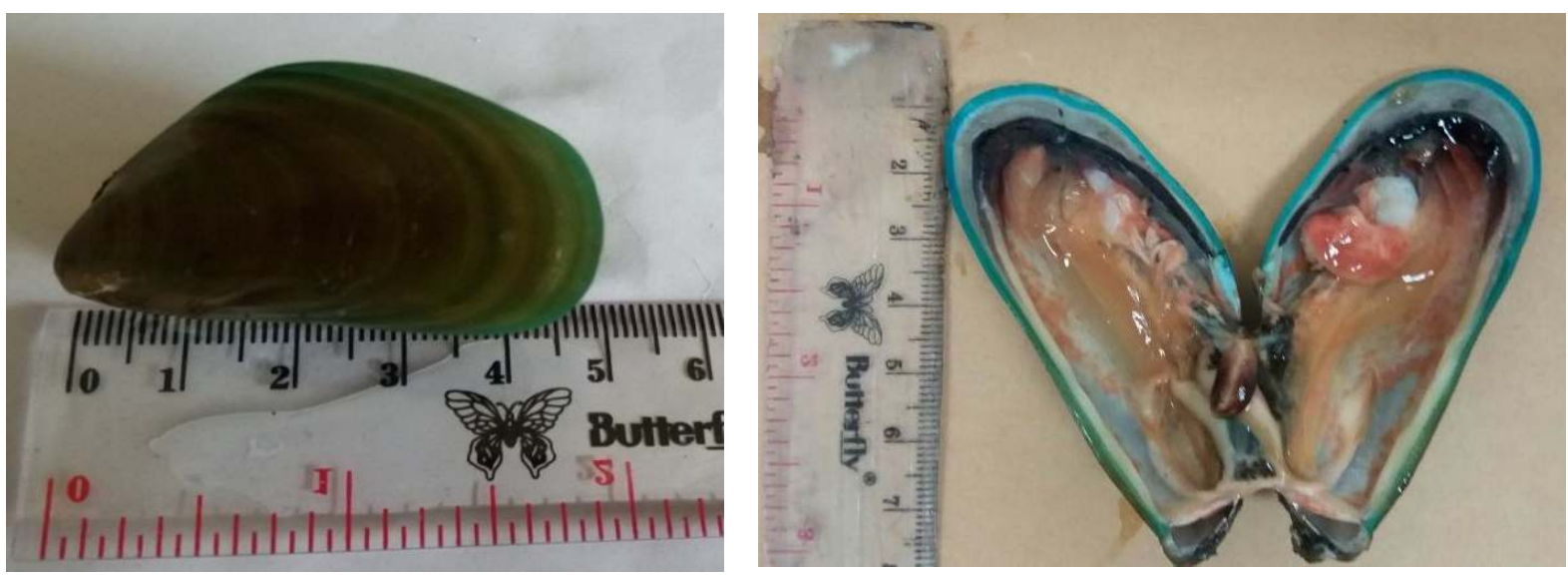

Gambar 2. Kerang hijau (Perna viridis) yang diperoleh saat penelitian

Figure 2.Green shellfish (Perna viridis) obtained during the study

Tabel 3. Konsentrasi TSS dan Pb pada air, sedimen dan Kerang Hijau (Perna viridis) selama penelitian

Table 3. Concentrations of TSS and Pb on water, sediment and Green Mussel (Perna viridis) during the study

\begin{tabular}{llclll} 
& & \multicolumn{3}{c}{ Parameters } \\
\cline { 3 - 6 } & & TSS & Pb on water & Pb on cediment & Pb on green mussel \\
\hline \multirow{2}{*}{ Stasiun 1 } & Ulangan ke-1 & 8 & 0.006 & 76.78 & 9.77 \\
& Ulangan ke-2 & $<8$ & 0.006 & 151.46 & 7.69 \\
& Ulangan ke-3 & $<8$ & 0.007 & 188.64 & 9.85 \\
& Mean & $<8$ & 0.01 & 138.9 & 9.10 \\
\hline \multirow{2}{*}{ Stasiun 2 } & Ulangan ke-1 & $<8$ & 0.006 & 78.82 & 6.07 \\
& Ulangan ke-2 & $<8$ & 0.006 & 215.67 & 6.30 \\
& Ulangan ke-3 & $<8$ & 0.006 & 157.12 & 6.86 \\
& Mean & $<8$ & 0.01 & 150.54 & 6.41 \\
\hline \multirow{2}{*}{ Stasiun 3 } & Ulangan ke-1 & $<8$ & 0.006 & 80.82 & 5.71 \\
& Ulangan ke-2 & $<8$ & 0.006 & 186.51 & 6.13 \\
& Ulangan ke-3 & $<8$ & 0.007 & 169.32 & 8.52 \\
& Mean & $<8$ & 0.006 & 145.5 & 6.77 \\
\hline
\end{tabular}




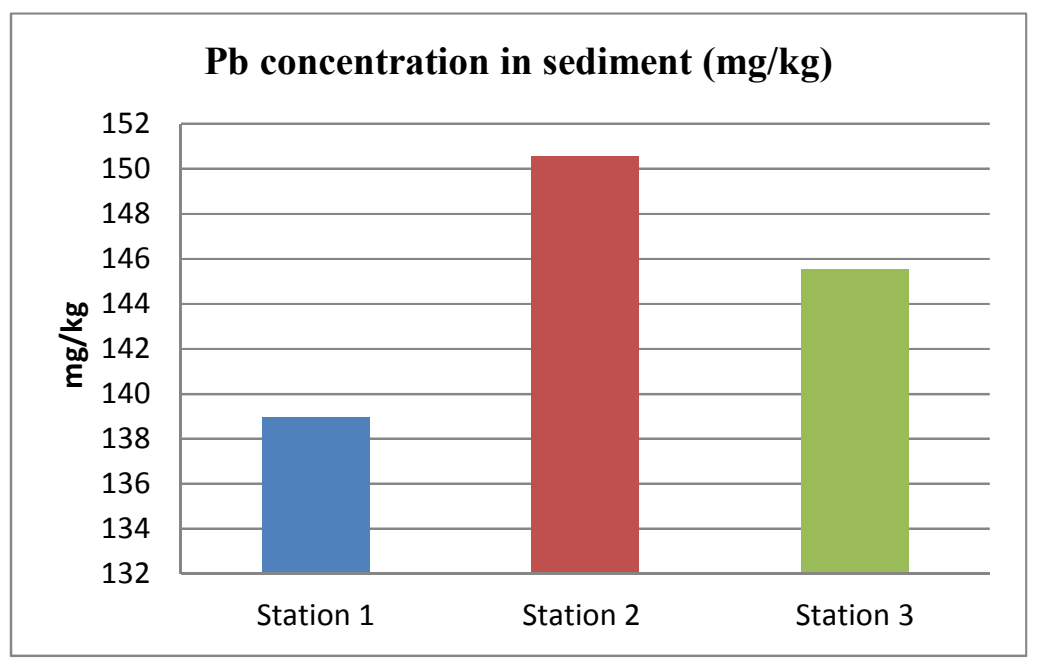

Gambar 3. Rata-rata konsentrasi $\mathrm{Pb}$ di sedimen selama penelitian

Figure 3. Average $\mathrm{Pb}$ concentrations in sediments during the study

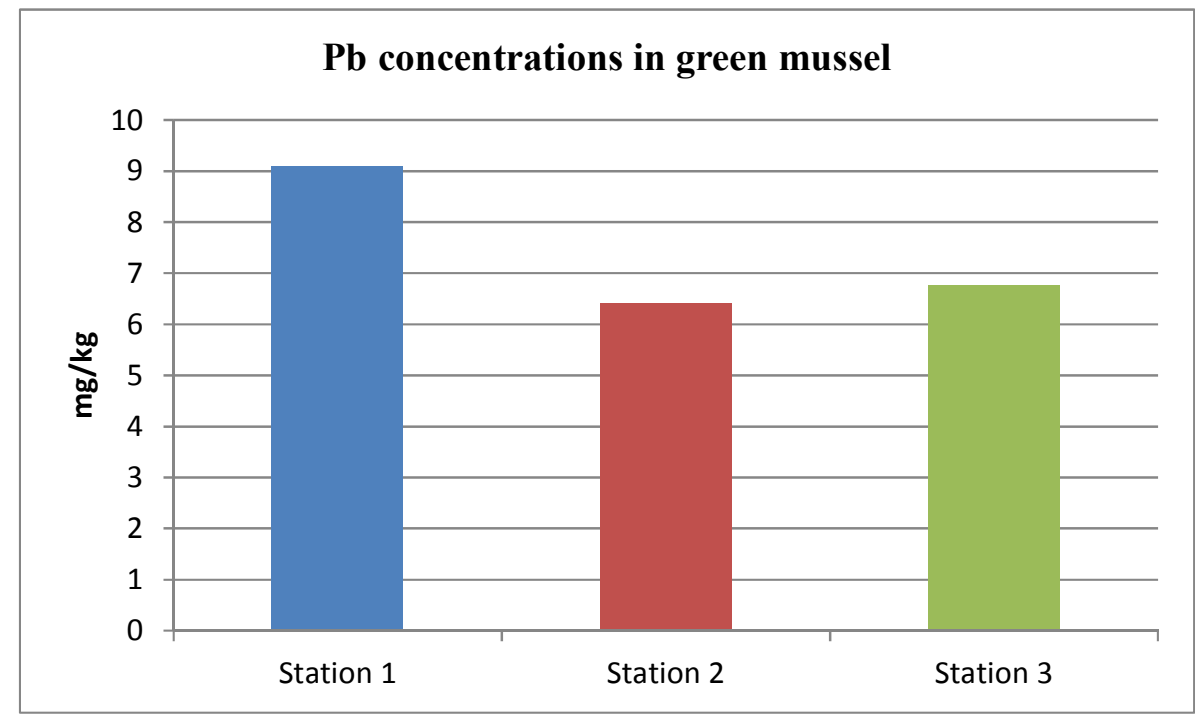

Gambar 4. Rata-rata konsentrasi $\mathrm{Pb}$ di kerang hijau selama penelitian Figure 4. Mean concentrations of $\mathrm{Pb}$ in green mussel during the study

Tabel 4. Nilai RQ dari total tingkat pemapaparan logam berat $\mathrm{Pb}$ pada masyarakat Perairan Cilincing Pesisir DKI Jakarta

Table 4. RQ value of the total level of exposure to $\mathrm{Pb}$ heavy metals in the community of Cilincing Waters, DKI Jakarta

\begin{tabular}{lcccccc}
\hline \multirow{2}{*}{\begin{tabular}{l} 
Exposure way of heavy metal \\
\cline { 2 - 7 }
\end{tabular}} & \multicolumn{2}{c}{ Cilincing Estuary } & \multicolumn{2}{c}{ Settlement Area } & \multicolumn{2}{c}{$\begin{array}{c}\text { Industrial zone } \\
\text { "Kawasan Berikat } \\
\text { Nusantara" }\end{array}$} \\
\cline { 2 - 7 } & Children & Adult & Children & Children & Adult & Children \\
\hline Ingestion of sediment & 0.00383 & 0.000284 & 0.004122 & 0.000322 & 0.0039871 & 0.0002995 \\
Ingestion of surface water & $8.21 \mathrm{E}-06$ & $1.76 \mathrm{E}-06$ & $8.21 \mathrm{E}-06$ & $1.76 \mathrm{E}-06$ & $8.9 \mathrm{E}-06$ & $1.9 \mathrm{E}-06$ \\
Ingestion of suspended matter & 0.30456 & 0.065267 & 0.329949 & 0.070702 & 0.3190199 & 0.0683608 \\
Dermal contact with sediment & 0.00396 & 0.0054 & 0.00424 & 0.0068 & 0.00415 & 0.0053 \\
Dermal contact with surface water & $3.12 \mathrm{E}-05$ & $6.34 \mathrm{E}-06$ & $3.12 \mathrm{E}-05$ & $6.34 \mathrm{E}-06$ & $3.38 \mathrm{E}-05$ & $6.86 \mathrm{E}-06$ \\
Total & 0.3123 & 0.07069 & 0.33839 & 0.07658 & 0.32719 & 0.07405 \\
RQ & \multicolumn{2}{c}{$\mathbf{1 3 4 6 . 3}$} & $\mathbf{1 4 5 8 . 4}$ & $\mathbf{1 4 1 0 . 1}$ \\
\hline
\end{tabular}


Oseanologi dan Limnologi di Indonesia 2018 3(3): 197-208

Tabel 5. Nilai Intake, ECR, RQ dan HI pada masyarakat Perairan Cilincing Pesisir DKI Jakarta

Table 5. Intake value, ECR, RQ and HI in the community of Cilincing Waters, DKI Jakarta

\begin{tabular}{cccccc}
\hline \multicolumn{2}{c}{ Cilincing Estuary } & \multicolumn{2}{c}{ Settlement Area } & \multicolumn{2}{c}{ Industrial zone "Kawasan Berikat } \\
Nusantara"
\end{tabular}

Tabel 6. Laju asupan aman konsumsi kerang hijau

Table 6.Safe consumption of green mussel consumption rate

\begin{tabular}{ccccc}
\hline \multirow{2}{*}{ Locations } & \multicolumn{2}{c}{$\begin{array}{c}\text { Consumption Rate } \\
\text { (g/day) }\end{array}$} & \multicolumn{2}{c}{$\begin{array}{c}\text { Frequency of Exposure } \\
\text { (day/year) }\end{array}$} \\
\cline { 2 - 5 } & Children & Adult & Children & Adult \\
\hline Station 1 & 0.01 & 0.06 & 0.01 & 0.07 \\
Station 2 & 0.02 & 0.09 & 0.02 & 0.10 \\
Station 3 & 0.02 & 0.09 & 0.02 & 0.09 \\
\hline
\end{tabular}

\section{Pembahasan}

\section{Konsentrasi Total Suspended Solid (TSS)}

Total Suspended Solid (TSS) dapat disebut juga sebagai total bahan organik dan anorganik yang tersuspensi diperairan. TSS erat kaitannya dengan tingkat kekeruhan air. Kekeruhan air dapat ditimbulkan oleh masuknya padatan tersuspensi, dan mengakibatkan berkurangnya laju fotosintesis fitoplankton yang merupakan sumber pakan bagi kerang hijau. Konsentrasi TSS yang diperoleh selama penelitian sangat kecil yaitu $<8 \mathrm{mg} / 1$ pada seluruh lokasi pengambilan sampel. Hal ini menunjukkan konsentrasi TSS masih sesuai dengan baku mutu yang ditetapkan oleh KepmenLH No. 51 Tahun 2004 untuk ekosistem koral dan lamun sebesar $20 \mathrm{mg} / \mathrm{l}$ dan $80 \mathrm{mg} / \mathrm{l}$ untuk ekosistem mangrove.

\section{Konsentrasi Pb di air}

Hasil pengukuran konsentrasi $\mathrm{Pb}$ di air berkisar antara $0,006 \mathrm{mg} / 1-0,007 \mathrm{mg} / \mathrm{l}$ dengan kisaran yang hampir sama pada masing-masing lokasi. Berdasarkan baku mutu biota laut pada Kepmen-LH No. 51 Tahun 2004 tentang baku mutu air laut untuk biota laut konsentrasi $\mathrm{Pb}$ air yaitu sebesar $0,008 \mathrm{mg} / 1$, sehingga konsentrasi $\mathrm{Pb}$ air masih sesuai dengan baku mutu. Salah satu faktor yang menyebabkan rendahnya konsentrasi logam $\mathrm{Pb}$ di air ialah pengambilan sampel dilakukan pada musim hujan dan dalam keadaan pasang sehingga konsentrasi logam $\mathrm{Pb}$ mengalami pengenceran. Hal ini sesuai dengan penelitian terkait $\mathrm{Pb}$ di air oleh Li Y et al. (2014) yang menyebutkan faktor yang mempengaruhi konsentrasi Timbal di Laut Cina Timur dipengaruhi oleh masukan dari aliran sungai, atmosfir, musim, tingkat adsorpsi dan co presipitasi dengan partikel tersuspensi.

\section{Konsentrasi Pb di Sedimen}

Selain mengetahui konsentrasi logam $\mathrm{Pb}$ di air, perlu juga diketahui konsentrasi $\mathrm{Pb}$ di sedimen. Logam akan terikat pada partikel dan tersedimentasi pada dasar perairan. Selain itu, kandungan logam berat dalam sedimen dapat digunakan untuk mengetahui tingkat risiko akibat paparan logam berat yang bersumber dari sedimen. Berdasarkan hasil penelitian rata-rata kandungan logam $\mathrm{Pb}$ di sedimen berkisar antara $138,96 \mathrm{mg} / \mathrm{kg}$ - 150,54 mg/kg. Pemerintah Indonesia belum membuat baku mutu logam pada sedimen di perairan, sehingga baku mutu yang di jadikan rujukan ialah Canadian Sediment Quality Guidelines for the Protection of Aquatic Life tahun 2001 (CCME 2001), yaitu baku mutu logam Timbal di sedimen adalah $30,2 \mathrm{mg} / \mathrm{kg}$. Jika dibandingkan dengan nilai CCME, maka kandungan $\mathrm{Pb}$ di sedimen Perairan Cilincing telah melewati baku mutu. Konsentrasi logam berat disedimen berkorelasi positif dengan kandungan karbon organik dan tekstur sedimen. Umumnya logam berat terabsorbsi baik pada sedimen 
bertekstur liat, lumpur dan halus (Raj et al. 2013). Berdasarkan pemantauan tekstur sedimen berkisar antara lumpur yang halus hingga sangat halus. Logam berat yang masuk ke perairan akan segera berasosiasi dengan partikel sedimen dan terakumulasi didasar perairan. Akumulasi logam berat dari air permukaan ke dasar perairan dipengaruhi oleh beberapa faktor lingkungan seperti $\mathrm{pH}$, kekuatan ion, masukan limbah antropogenik, komposisi nutrisi, jenis kandungan organik dan ukuran partikel (Aprile dan Bouvy 2008).

\section{Konsentrasi Pb di Kerang Hijau}

Kerang hijau merupakan salah satu bahan pangan yang digemari masyarakat pesisir, selain karena harganya yang murah, daging kerang hijau enak dan gurih saat dikonsumsi. Badan Pengawas Obat dan Makanan (BPOM) tahun 2009 menetapkan batasan maksimum cemaran logam berat $\mathrm{Pb}$ pada kerang sebesar $1,5 \mathrm{mg} / \mathrm{kg}$. Hal tersebut menunjukkan konsentrasi $\mathrm{Pb}$ di kerang hijau pada semua lokasi pengamatan telah melewati baku mutu. Simbolon et al. (2014) melakukan penelitian di pesisir Kabupaten Tangerang dan menunjukkan konsentrasi $\mathrm{Pb}$ di kerang simping juga telah melewati baku mutu. Kandungan $\mathrm{Pb}$ yang tinggi pada kerang akan mengakibatkan efek merugikan bagi kesehatan masyarakat yang mengkonsumsinya. Riani et al. (2018) menjelaskan kerang hijau pada Muara Kamal telah melewati baku mutu dan telah mengalami malformasi pada bagian tubuhnya.

\section{Risiko Kesehatan Pencemaran Logam Berat Pb di Perairan Cilincing Pesisir DKI Jakarta}

\section{Tingkat Risiko Akibat Aktivitas Langsung}

Metode analisis risiko kesehatan yang digunakan untuk menghitung nilai risiko masyarakat pesisir yang melakukan aktivitas langsung menggunakan model analisis risiko SEDISOIL menurut Albering et al. (1999) aktivitas yang umumnya dilakukan secara langsung di perairan Cilincing antara lain, memancing, berenang dan memperbaiki kapal. Nilai risiko bisa diterima dan tidak berbahaya jika nilainya kurang dari satu $(\mathrm{RQ}<1)$. Kenyataannya nilai RQ di semua lokasi pengamatan menunjukkan nilai lebih dari 1 (RQ>1). Dengan demikian masyarakat Cilincing Pesisir DKI Jakarta memiliki risiko kesehatan akibat paparan logam berat. Oleh karena itu Perairan Cilincing Pesisir DKI Jakarta memerlukan manajemen risiko kesehatan terhadap pencemaran logam $\mathrm{Pb}$. Kondisi ini serupa dengan pesisir Kabupaten Tangerang yang menujukkan bahwa konsentrasi logam $\mathrm{Pb}, \mathrm{Cd}$ dan $\mathrm{Zn}$ telah memiliki nilai RQ di atas 1, sehingga masyarakat yang beraktivitas langsung diperairan tersebut memiliki risiko kesehatan terhadap logam berat khususnya $\mathrm{Pb}, \mathrm{Cd}$ dan Zn (Simbolon et al. 2014).

\section{Tingkat Risiko Akibat Konsumsi Kerang hijau}

Logam berat $\mathrm{Pb}$ merupakan logam yang bersifat karsinogenik, sehingga tingkat risiko karsinogen untuk timbal didefinisikan sebagai banyaknya intake harian kronik dikalikan dengan faktor slope karsinogenik yang didapatkan dari perkiraan daya racun. Estimasi risiko kesehatan karena konsumsi kerang hijau dilakukan sesuai dengan berat badan kelompok populasi dewasa yaitu $70 \mathrm{~kg}$ dan anak yaitu $15 \mathrm{~kg}$ (US-EPA 2005).

Penelitian ini menghasilkan nilai RQ lebih dari 1 dan nilai ECR yang telah melebihi $10^{-4}$ di semua stasiun pengambilan sampel, sehingga kerang hijau memiliki risiko kesehatan terhadap efek nonkarsinogenik dan efek karsinogenik logam timbal. Pada model risiko ini, risiko terjadi jika kerang hijau dikonsumsi sebanyak 180 gr/hari selama 48 hari/tahun. Model risiko digunakan untuk jangka waktu 30 tahun maka efek toksisitas logam Timbal akan dirasakan pada 30 tahun mendatang.

Sebagai pembanding, El Nemr et al. (2012) melakukan penelitian pada masyarakat yang mengkonsumsi moluska di Muara Mediterania Mesir menghasilkan nilai RQ pada moluska untuk logam $\mathrm{Pb}, \mathrm{Cd}$ dan $\mathrm{Zn}$ masih di bawah $1(\mathrm{RQ}<1)$, sehingga masyarakat di sekitar Muara Mediterania Mesir masih belum berisiko terhadap paparan logam berat. Demikian halnya dengan penelitian Bogdanovic et al. (2014) yang melakukan penelitian analisis risiko kesehatan akibat konsumsi kerang yang berasal dari Perairan Kroasia, sehingga konsumsi kerang dari Perairan Kroasia belum berisiko terhadap kesehatan.

\section{Manajemen Risiko Kesehatan}

Perbedaan besaran nilai RQ dan ECR tiap lokasi pengambilan sampel tidak menggambarkan tinggi atau rendahnya risikonya yang terjadi. Analisa ini digunakan untuk mengetahui berisiko atau tidaknya suatu populasi yang berdampak. Apabila nilai RQ telah melebih 1 maka dibutuhkan manajemen risiko. Berdasarkan hasil dan pembahasan diatas, masyarakat di perairan Cilincing pesisir DKI Jakarta memiliki risiko kesehatan akibat paparan logam berat dengan nilai RQ dimasing-masing lokasi penelitian telah melebihi 1 (RQ>1). Tingkat risiko kesehatan dapat dicegah dengan menggunakan manajemen risiko. Berdasarkan hasil manajemen risiko pada Tabel 5 untuk konsumsi aman kerang hijau bagi masyarakat di perairan Cilincing Pesisir DKI Jakarta, maka dianjurkan agar masyarakat 
mengkonsumsi kerang hijau maksimal 0,06 gram/hari. Manajemen risiko juga perlu dilakukan dengan melakukan pengelolaan dari sumber logam Timbal, seperti pengendalian jumlah limbah industri yang terdapat disepanjang wilayah Cilincing dan sekitarnya. Pengawasan dari Dinas Lingkungan Hidup DKI Jakarta perlu dilaksanakan agar kualitas limbah yang masuk ke aliran sungai dapat terkontrol dengan baik. Penegakan hukum dan efek jera bagi para pelaku industri yang tidak melaksanakan prosedur pengolahan limbah juga harus diterapkan dengan lebih baik. Kebiasaan masyarakat yang membuang limbah cair maupun padat langsung ke perairan semakin memperburuk kondisi pencemaran di wilayah ini. Simbolon (2017) menjelaskan sikap peduli masyarakat dikawasan Cilincing masih tergolong kurang baik, sehingga peran aktif masyarakat dan industri perlu ditingkatkan untuk pengendalian pencemaran logam Timbal. Kepedulian masyarakat terhadap pentingnya kesehatan lingkungan pesisir sangat diperlukan dalam mengelola kawasan perairan yang berkelanjutan.

\section{Kesimpulan}

Konsentrasi logam Timbal pada kerang hijau dan sedimen di perairan Cilincing, pesisir DKI Jakarta telah melebihi baku mutu. Masyarakat pesisir Cilincing berisiko kesehatannya akibat pencemaran Timbal. Manajemen risiko dapat dilakukan dengan cara mengurangi laju asupan konsumsi kerang hijau. Disamping itu perlu pengendalian dan pengawasan menyeluruh oleh pemerintah, dan penegak hukum terhadap industri serta peningkatan partisipasi masyarakat dalam pengelolaan perairan Cilincing pesisir DKI Jakarta yang berkelanjutan.

\section{Persantunan}

Penelitian ini dibiaya oleh Kemenristek DIKTI, sehingga penulis mengucapkan terimakasih khususnya kepada Direktorat Riset dan Pengabdian Masyarakat Direktorat Jenderal Penguatan Riset dan Pengembangan, Kementrian Riset Teknologi dan Pendidikan tinggi. Terimakasih disampaikan kepada suami penulis Daniel Rezki Sitohang, M.Si dan orangtua penulis Nippon Simbolon yang membantu penulis dalam pengambilan sampel. Terimakasih diberikan kepada anak Raphael Baharaja Sitohang. Terimakasih juga disampaikan kepada Faradiba M.Sc, Ratna Sabina, S.Pd, Rosa Medina Girsang,
S.Pd dan Frans yang membantu penulis dalam pengumpulan data dan preparasi sampel.

\section{Daftar Pustaka}

Aprile, F. M., dan M. Bouvy. 2008. Distribution and enrichment of heavy metals in sediments at The Tapacurá River Basin, Northeastern Brazil. Brazilian. Journal Aquatic Science Technology 12(1):1-8.

Albering, J.H., J,P. Rila., E. J.C. Moonen, J. A. Hoogewarf., dan J. C.S.Kleijans. 1999. Human health risk assessment in relation to environmental pollution of two artificial freshwater lakes in the Netherlands. Environmental Health Perspectives 107 (1): 27-35.

Badan Pusat Statistik (BPS). 2015. Badan Pusat Statistik DKI Jakarta. Available: http://bappedajakarta.go.id/?page_id=1131. (9 Februari 2018).

Besser, J. M., W. G. Brumbaugh., T. W. May., dan C. J. Schmitt. . 2007. Biomonitoring of lead, zinc, and cadmium in streams draining lead-mining and non-mining areas, Southeast Missouri, USA. Environmental Monitoring Assessment 129 (1): 227-241.

Bogdanovic, T., I. Ujevic, M. Sedak, E. Listes, V. Simat., S. Petricevic., dan V. Poljak. 2014. $\mathrm{As}, \mathrm{Cd}, \mathrm{Hg}$ and $\mathrm{Pb}$ in four edible shellfish species from breeding and harvesting areas along The Eastern Adriatic Coast, Croatia. Food Chemistry, 146 (1): 197-203.

BPOM (Badan Pengawasan Obat dan Makanan). 2009. Peraturan Kepala Badan Pengawas Obat dan Makanan Republik Indonesia Tentang Penetapan Batas Maksimum Cemaran Mikroba dan Kimia dalam Makanan.11 pp.

CCME (Canadian Council of Ministers of the Environment) 2001. Canadian Sediment Quality Guidelines for the Protection of Aquatic Life. Canada. Canadian Environmental Quality Guidelines. Available:

http://stts.ccme.ca/en/index.html?chems $=124$ \&chapters $=3$. (23 Desember 2017).

El Nemr, A., A. K.haled.., A. Mooner, dan A. E. Sikaily . 2012. Risk probability due to heavy metals in bivalve from Egyptian Mediterranean coast. Egyptian Journal of Aquatic Research 38(2): 67-75.

Hutabarat S dan Evans SM. 2008. Pengantar Oseanografi. UI Press, Jakarta. -

IRIS (Integrated Risk Information System). 2007. Integrated Risk Information System List of 
Substance. Available: http:// www.epa.gov/iris/subst/index.html. ( 23 Desember 2017).

IPCS (The International Programme on Chemical Safety). 2004. Environmental Health Criteria XXX: Principles for Modelling Dose-Response for The Risk Assessment of Chemicals. World Health Organization and International Programme on Chemical Safety. International Programme on Chemical Safety. Geneva. $25 \mathrm{pp}$.

KMNLH (Kementerian Lingkungan Hidup). 2004. Keputusan Menteri Negara dan Lingkungan Hidup No.51 tentang Baku Mutu Air Laut untuk Kehidupan Biota Laut. 11 pp.

Li, Y., R. Yang., A. Zhang, dan S. Wang. 2014. The distribution of dissolved Lead in the coastal waters of the East China Sea. Marine Pollution Bulletin 85(2):700-709.

Lestari dan Edward. 2004. Dampak pencemaran logam berat terhadap kualitas air laut dan sumberdaya perikanan (studi kasus kematian massal ikan-ikan di Teluk Jakarta). Makara Sains 8(2): 52-58.

Raj, S., J. P. Kumar., dan P. J. Ranjan. 2013. Textural and heavy metal distribution in sediments of Mahanadi estuary, East Coast of
India. Indian Journal of Geo-Marine Sciences 42(3): 370-374.

Riani, E., M. R. Cordova., dan Z. Arifin. 2018. Heavy metal pollution and its relation to the malformation of green mussels cultured in Muara Kamal waters, Jakarta Bay, Indonesia. Marine Pollution Bulletin133: 664-670

Simbolon, A. R., E. Riani, dan Y. Wardiatno. 2014. Analisis resiko kesehatan pencemaran logam beratpadaair, sedimen, dan simping (Placuna placenta) di Pesisir Kabupaten Tangerang. Jurnal Pengelolaan Sumberdaya Alam dan Lingkungan 4(1): 73-81.

Simbolon, A. R. 2016. Status pencemaran di Perairan Cilincing Pesisir DKI Jakarta. Prosiding dari Seminar Nasional XIII Pendidikan Biologi FKIP UNS. Universitas Sebelas Maret. 677-682.

Simbolon, A. R. 2017. Karakteristik dan sikap peduli lingkungan masyarakat Pesisir Kawasan Cilincing DKI Jakarta. Jurnal Pro life 4(3):456-466.

USEPA (U.S. Environmental Protection Agency). 2005. Guidelines for Carcinogen Risk Assessment. Risk Assessment Forum. United States Environmental Protection Agency., Washington, DC.134 p 